\title{
B vitamin blood concentrations and one-carbon metabolism polymorphisms in a sample of Italian women and men attending a unit of transfusion medicine: a cross-sectional study
}

\author{
Renata Bortolus $^{1}$ (1) - Francesca Filippini ${ }^{1}$ (1) - Silvia Udali ${ }^{2} \cdot$ Marianna Rinaldi $^{3} \cdot$ Sabrina Genesini $^{3} \cdot$ Giorgio Gandini $^{3}$.

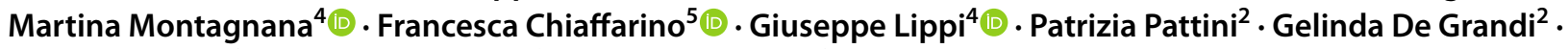

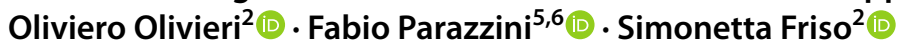

Received: 26 February 2020 / Accepted: 24 November 2020 / Published online: 29 December 2020

(c) The Author(s) 2020, corrected publication 2020

\begin{abstract}
Purpose To define blood status of folate, vitamin B12, vitamin B6, homocysteine, and major one-carbon metabolism-related polymorphisms in healthy, males and females blood donors, aged 18-65 years were evaluated. General characteristics and lifestyle factors were also investigated.

Methods An explorative cross-sectional study design was used to evaluate a sample of blood donors attending the Unit of Transfusion Medicine of the Verona University Hospital, Italy. From April 2016 to May 2018, 499 subjects were enrolled (255 men, 244 women of whom 155 of childbearing age). Major clinical characteristics including lifestyle and dietary habits, $\mathrm{B}$ vitamins and homocysteine were analyzed. The MTHFR $677 \mathrm{C}>\mathrm{T}, c S H M T 1420 \mathrm{C}>\mathrm{T}$, DHFR $19 \mathrm{bp}$ ins/del, RFC1 80 $\mathrm{G}>\mathrm{A}$ polymorphisms were also determined.

Results Mean plasma concentrations of folate, vitamin B12, vitamin B6 and homocysteine were $14.2 \mathrm{nmol} / \mathrm{L}$ (95\% CI 13.714.8), $271.9 \mathrm{pmol} / \mathrm{L}$ (95\% CI 262.6-281.5), $51.0 \mathrm{nmol} / \mathrm{L}$ (95\% CI 48.7-53.4) and $13.5 \mu \mathrm{mol} / \mathrm{L}$ (95\% CI 13.1-14.0), respectively. Plasma folate, was adequate $(>15 \mathrm{nmol} / \mathrm{L})$ in $44.7 \%$ of all subjects, $39.0 \%$ of males and $42.5 \%$ of women $<45$ years. Similarly, vitamin B12 was adequate ( $>350 \mathrm{pmol} / \mathrm{L})$ in $25.1 \%$ of all subjects and in $20.3 \%$ of men $\geq 45$ years. The rare allele frequencies were 0.21 for MTHFR 677TT, 0.11 for $c S H M T$ 1420TT, 0.18 for DHFR $19 \mathrm{bp}$ del/del, 0.20 for RFCl 80AA, and a gene-nutrient interaction was confirmed for folate concentrations according to MTHFR $677 \mathrm{C}>\mathrm{T}$ and $D H F R 19 \mathrm{bp}$ del/del. Conclusion An Italian sample of healthy blood donors shows that an adequate concentration of plasma folate and vitamin B12 is reached only in a limited percentage of subjects, thus encouraging consideration for specific public health strategies.
\end{abstract}

Keywords Folate $\cdot$ Vitamin B12 $\cdot$ Vitamin B6 $\cdot$ One-carbon polymorphisms

Simonetta Friso

simonetta.friso@univr.it

1 Office for Research Promotion, Verona University Hospital, Verona, Italy

2 Unit of Internal Medicine, Department of Medicine, University of Verona School of Medicine, Verona, Italy

3 Unit of Transfusion Medicine, Verona University Hospital, Verona, Italy

4 Section of Clinical Biochemistry and Hematology, Verona University Hospital, Verona, Italy

5 Department of Woman, Newborn and Child, Fondazione Istituto di Ricovero e Cura a Carattere Scientifico (IRCCS) Ca' Granda Ospedale Maggiore Policlinico, Milan, Italy

6 Department of Clinical Sciences and Community Health, Università Degli Studi di Milano, Milan, Italy

$\begin{array}{ll}\text { Abbreviations } \\ \text { BMI } & \text { Body mass index } \\ \text { CI } & \text { Confidence interval } \\ \text { cSHMT } & \text { Cytosolic serine hydroxymethyltransferase } \\ \text { DHFR } & \text { Dihydrofolate reductase } \\ \text { EDTA } & \text { Ethylenediaminetetraacetic acid } \\ \text { HPLC } & \text { High-performance liquid chromatography } \\ \text { MTHFR } & \text { Methylenetetrahydrofolate reductase } \\ \text { NTDs } & \text { Neural tube defects } \\ \text { OR } & \text { Odds ratio } \\ \text { PBMCs } & \text { Peripheral blood mononuclear cells } \\ \text { PLP } & \text { Pyridoxal 5'-phosphate } \\ \text { RBCs } & \text { Red blood cells } \\ \text { RCFs } & \text { Red cell folates } \\ \text { RFC1 } & \text { Reduced folate carrier 1 }\end{array}$


SD Standard deviation

tHcy Total homocysteine

\section{Introduction}

B vitamins are important to define the health status of a population because of their major role in affecting the risk of neural tube defects (NTDs) [1] and major chronic diseases [2-4]. The awareness of their precise blood concentrations is, therefore, a main issue to design public health policies [5] and even more so in a population without mandatory fortification especially if one considers the importance of establishing regional and national reference values. Only few data, however, are so far available from studies conducted in Italy on the average blood levels for B vitamins [6-8]. Recently, surveys conducted on Italians' eating habits have shown that adherence to Mediterranean diet has decreased considerably over the last few years [9]. A study conducted in Central Italy among blood donors showed that total B vitamins levels were lower than those considered appropriate in men and women [7]. Similarly, a study conducted among pregnant women showed that the average red blood cells (RBCs) folate levels and plasma folate concentrations were at the lowest extreme of the range values at the beginning of pregnancy (8th-10th week of gestation) in women not reporting current use of folic acid supplementation [6].

Considering the interest of defining B vitamins intake with the diet for a clear definition of dietary policies together with the possible indication of supplement use, it is important to measure in a sample of healthy men and women, their plasma levels of folate and other major B vitamins, namely B12 and the active form of vitamin B6, pyridoxal 5'-phosphate (PLP), as well as that of homocysteine (tHcy). Onecarbon metabolism-related genes should be also taken into account for their role in modulating vitamin concentrations and eventually the risk of diseases, in a gene-nutrient interaction manner [3, 8]. In this regard, the 5,10-methylenetetrahydrofolate reductase $(M T H F R)$ 677C $>\mathrm{T}$ polymorphism is considered a paradigmatic example for gene-nutrient interactions affecting folate metabolism and potentially the disease risk $[8,10]$. As for other polymorphic sites in folatemetabolism-related genes, the insertion/deletion (19 bp ins/ del) at dihydrofolate reductase (DHFR) gene [11] has also an important role for biochemical modification of folaterelated tHcy metabolism [12]. Furthermore, the reduced folate carrier $1(R F C 1)$ gene $80 \mathrm{G}>\mathrm{A}$ polymorphism is of considerable interest for its function in guaranteeing adequate folate absorption [13]. A functional polymorphism described in $c S H M T$ gene, the $1420 \mathrm{C}>\mathrm{T}$, affects the ability of the enzyme to pursue either the nucleotide synthesis or the methyl group provision within the folate-related one-carbon metabolism [14]. The allele frequency for those polymorphisms is yet mostly unknown in the general population though of interest for their link with B vitamins.

The primary objective of this study was to measure, in a sample of men and women ranging 18-65 years of age and attending a Unit of Transfusion Medicine, their nutritional status by the assessment of plasma concentrations of folate, vitamin B12, vitamin B6 and tHcy. The main determinants of $\mathrm{B}$ vitamins were also considered, as were the genotyping for MTHFR $677 \mathrm{C}>\mathrm{T}$, cSHMT $1420 \mathrm{C}>\mathrm{T}$, DHFR $19 \mathrm{bp}$ ins/ del, RFC1 $80 \mathrm{G}>\mathrm{A}$.

\section{Subjects and methods}

\section{Study design and participants}

From April 2016 to May 2018, 551 healthy blood donors, consecutively attending the Unit of Transfusion Medicine of the Verona University Hospital, Italy were asked to participate to this cross-sectional study, of them 538 subjects (97.6\%) agreed. In Italy blood donors are allowed to donate whole blood four times per year as a maximum, and two times per year for women in childbearing age. In the Unit of Transfusion Medicine of the Verona University Hospital donors are only admitted periodically for a mean number of 2.1 blood donations per year. Exclusion criteria were vitamins supplementation during the last 2 months before the blood sample withdrawal. Among all the participants, 37 were excluded after enrolment into the study, because they subsequently reported supplementation with folic acid and/ or other vitamins during the 2 months prior to the blood sample withdrawal. Blood samples values from two other subjects were not considered for the data analyses due to preanalytical technical problems. Overall, 499 subjects were enclosed into the study ( 255 men, 244 women: of these 155 were of childbearing age 18-44 years).

During the visit for blood donation enrolment, each eligible subject, after a detailed explanation of the study by the researcher, was invited to participate. After giving written informed consent, each participant was interviewed about his/her general characteristics, medical history and current therapy. Lifestyle and dietary habits including alcohol and smoking habits, fruits and vegetables consumption were also recorded. For fruits and vegetables one portion was defined as $150 \mathrm{~g}$ and $100 \mathrm{~g}$, respectively.

\section{Laboratory parameters}

Venous whole blood samples were withdrawn after an overnight fasting into Vacutainer ${ }^{\circledR}$ tubes containing ethylenediaminetetraacetic acid (EDTA) as anticoagulant to obtain 
plasma or without anticoagulant to obtain serum, as appropriate for the specific analyses.

After centrifugation at $1.500 \mathrm{~g}$ for $10 \mathrm{~min}$ at room temperature, plasma was separated, stored in aliquots and kept frozen at $-70{ }^{\circ} \mathrm{C}$ until measurements. Plasma folate and vitamin $\mathrm{B} 12$ concentrations were measured by an automated chemiluminescence method on Cobas e801 (Roche Diagnostics, Mannheim, Germany). Vitamin B6 was measured as PLP, its active form, by high-performance liquid chromatography (HPLC) with fluorometric detection [4]. Plasma tHcy concentrations were determined by an automated chemiluminescence method on ADVIA Centaur (Siemens Diagnostics) [3].

Venous blood was withdrawn from each subject into Vacutainer® tubes containing EDTA as anticoagulant after an overnight fast and stored at $-20{ }^{\circ} \mathrm{C}$ until analysis for genotyping, DNA was extracted from peripheral blood mononuclear cells (PBMCs) by Wizard Genomic DNA Purification Kit (Promega Corporation, Fitchburg, WI, USA). Genotyping for one-carbon-related polymorphisms (MTHFR 677 C $>$ T, $c S H M T 1420$ C $>\mathrm{T}$, DHFR 19 bp ins/del, $R F C 180 \mathrm{G}>\mathrm{A}$ ) were analysed by different methods: MTHFR 677C $>\mathrm{T}$ (rs1801133) [15], cSHMT 1420C $>\mathrm{T}$ (rs 1979277) [16], DHFR 19 bp ins/del (rs70991108) [17], RFCl 80G $>$ A (rs1051266) [13] and by PCR followed by restriction fragment length polymorphism assays. Data on genotyping were not determined due to poor yield for one sample.

The adequate status of plasma folate, vitamin B12 and tHcy was defined according to previous reports by others [2, 7] as follows: folate $>15 \mathrm{nmol} / \mathrm{L}$, vitamin $\mathrm{B} 12>350 \mathrm{pmol} / \mathrm{L}$ and tHcy $<10 \mu \mathrm{mol} / \mathrm{L}$. The concentration of plasma PLP $>35 \mathrm{nmol} / \mathrm{L}$ [4], was defined adequate [18]. Considering the significance of $\mathrm{B}$ vitamins in women or men of different age, data were analysed according to different age and gender categories. In women of childbearing age the risk of NTDs in pregnancy was modelled by Daly et al. [19]: the risk increased when maternal plasma folate concentration was less than $15.9 \mathrm{nmol} / \mathrm{L}$. Chen MY et al. [20] indicated that optimal RBC folate concentration was associated with a mean plasma folate concentration of $25.5 \mathrm{nmol} / \mathrm{L}$ : when this cut-off was considered, the risk increased for maternal plasma folate concentration $<25.5 \mathrm{nmol} / \mathrm{L}$.

\section{Statistical analysis}

The data were collected in a specific database after a review for completeness, consistency and plausibility.

The primary objective of this study was to estimate the frequency of adequate plasma folate concentrations $(>15 \mathrm{nmol} / \mathrm{L})$ in the whole study population and separately among men and women. We foresaw to include into the study about 250 women and 250 men. With this sample size we were able to obtain an estimate of adequate plasma folate concentration with narrow 95\% confidence interval (CI). For example, considering separately men and women, the expected 95\% CI were, respectively, 43.6-56.4 if the adequate plasma folate concentrations were $50 \%$ or $69.4-80.4$ if the value was $70 \%$, a frequency close to that reported by Zappacosta et al. [7].

Continuous variables were calculated by mean \pm standard deviation (SD), while logarithmic transformation was used for non-normal distribution variable and geometric means and CIs were used, as appropriate. Categorical variables were presented by calculating absolute frequency and percentage. The $95 \%$ CIs of the mean and proportion were provided to assess the precision of the estimates. Genetic data were analysed to evaluate the frequency of each genotype in the population studied after evaluating the Hardy Weinberg equilibrium. Considering the well-known role of gene-nutrient interactions within folate and B vitamin metabolism, separate analysis was performed according to plasma concentrations of folate by considering the median values, according to MTHFR $677 \mathrm{C}>\mathrm{T}, c S H M T 1420 \mathrm{C}>\mathrm{T}$, DHFR 19 bp ins/del, RFCl 80G $>$ A, genotypes.

Categorical variables were compared using the Pearson or Mantel-Haenszel Chi-square, as appropriate. Continuous variables were analyzed using analysis of variance, after logarithmic transformation if needed, or Kruskal-Wallis test when appropriate. We considered a two-tailed $P$ value of $<0.05$ to be significant. Odds Ratios (ORs) for inadequate status of plasma folate, vitamin B12, vitamin B6 and tHcy according to sociodemographic and general characteristics were computed. To take into account potential confounding factors, we used unconditional multiple logistic regression, with maximum likelihood fitting including in the model terms for gender, age, education, body mass index (BMI), smoking, alcohol drinking, fruits and vegetables consumption and physical activity. All the analyses were performed using the SAS software, version 9.4 (SAS Institute, Inc, Cary, NC, USA).

\section{Results}

\section{Characteristics of the study population}

The flow diagram of the study is reported in Fig. 1. Sociodemographic and general characteristics of the subjects according to age and gender are shown in Table 1.

\section{Biochemical parameters}

In the study population mean plasma folate concentrations were $14.2 \mathrm{nmol} / \mathrm{L}$ (95\% CIs 13.7-14.8), plasma vitamin B12 concentrations were $271.9 \mathrm{pmol} / \mathrm{L}$ (95\% CIs 262.6-281.5) 
Fig. 1 Flow diagram of the study design

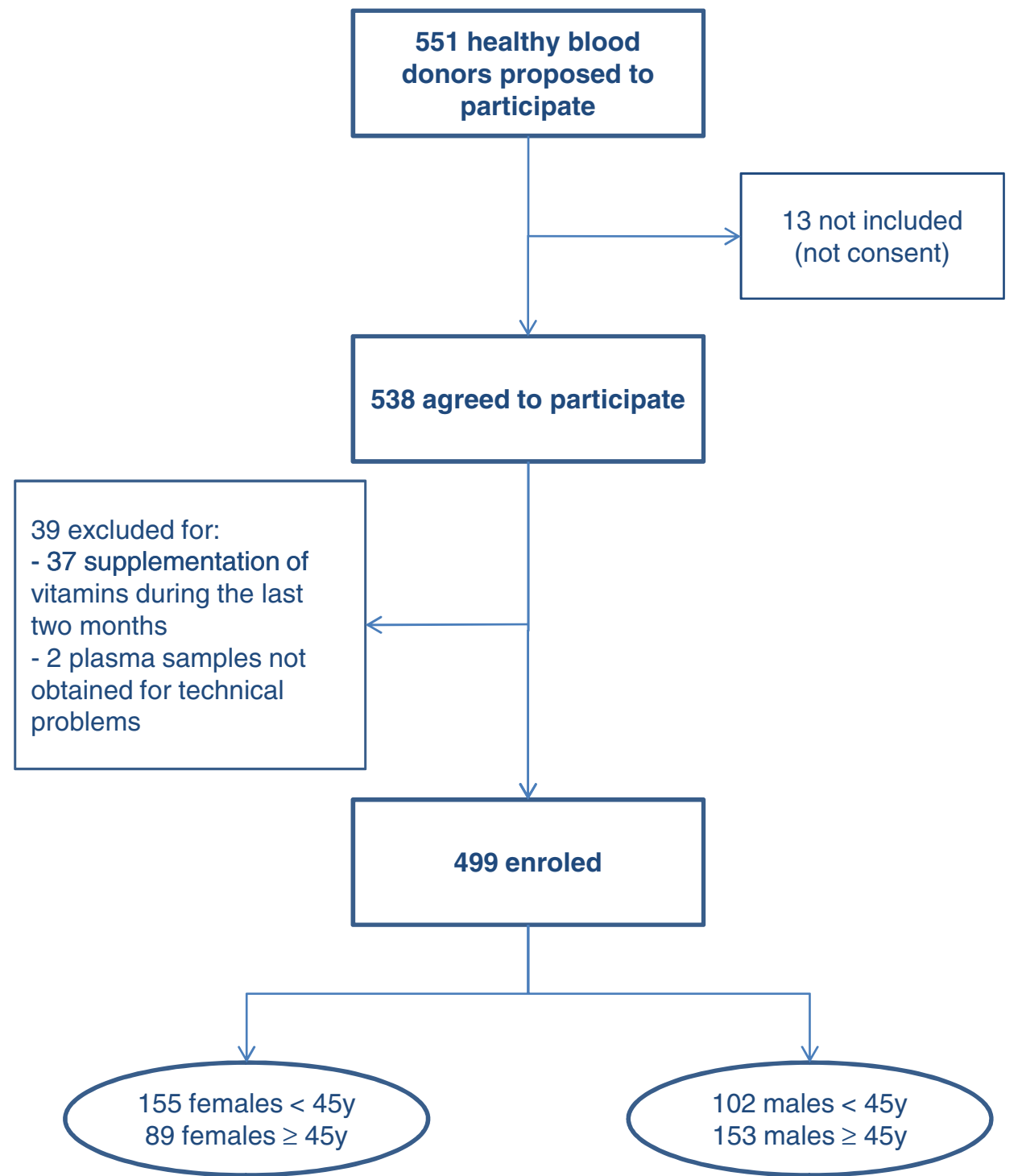

and mean plasma vitamin B6 $51.0 \mathrm{nmol} / \mathrm{L}$ (95\% CIs 48.7-53.4); plasma tHcy concentrations were $13.5 \mu \mathrm{mol} / \mathrm{L}$ (95\% CIs 13.1-14.0). Females showed higher plasma folate concentrations as compared to males, while males had significantly higher plasma concentrations of vitamin B6 and tHcy (Table 2). As shown in Table 2, females $<45$ years of age had lower plasma folate concentration compared to females of age $\geq 45$ years, as expected, while males $<45$ years had higher plasma concentrations of vitamin B12, B6 and lower tHcy as compared to males $\geq 45$ years.

Adequate plasma folate concentrations, defined for values $>15 \mathrm{nmol} / \mathrm{L}$, were observed in $44.7 \%$ of blood donors. Adequate vitamin B12 concentrations, as defined for values $>350 \mathrm{pmol} / \mathrm{L}$, were observed in $25.1 \%$ of total blood donors and in $20.3 \%$ of men $\geq 45$ years. Adequate vitamin B6 concentrations, defined for values $>35 \mathrm{nmol} / \mathrm{L}$, were observed in $77.7 \%$ of total blood donors (Table 2).
Among females and males $<45$ years, $42.5 \%$ and $39.0 \%$ showed adequate plasma folate concentrations, respectively (Table 2 ). When the cut-off $\geq 15.9 \mathrm{nmol} / \mathrm{L}$ was considered for women at childbearing age [19], 39.9\% showed adequate concentrations. Chen et al. [20] indicated that optimal RBC folate concentration was associated with a mean plasma folate concentration of $25.5 \mathrm{nmol} / \mathrm{L}$ : when this cut-off was considered, $11.8 \%$ showed adequate concentrations. Total plasma tHcy concentrations defined as ideal if $<10 \mu \mathrm{mol} / \mathrm{L}$, were observed in $16.1 \%$ of total blood donors (Table 2). Concentrations of tHcy inversely correlated, as expected, with plasma levels of folate and vitamin B12 (data not shown).

In Table 3, the age $\geq 35$ years and the intake of at least two portions/day of fruits and vegetables were associated with adequate concentrations of plasma folate. Regarding 
Table 1 Sociodemographic and general characteristics of the subjects according to age and gender

\begin{tabular}{|c|c|c|c|c|c|c|c|}
\hline & Total $n(\%)$ & $\begin{array}{l}\text { Females }<45 \text { years } \\
n(\%)\end{array}$ & $\begin{array}{l}\text { Females } \geq 45 \text { years } \\
n(\%)\end{array}$ & $P$ value* & $\begin{array}{l}\text { Males }<45 \text { years } \\
n(\%)\end{array}$ & $\begin{array}{l}\text { Males } \geq 45 \text { years } \\
n(\%)\end{array}$ & $P$ value* \\
\hline \multicolumn{8}{|l|}{ Age (years) } \\
\hline$\leq 34$ & $124(24.9)$ & $94(60.7)$ & & & $30(29.4)$ & & \\
\hline $35-44$ & $133(26.7)$ & $61(39.4)$ & & & $72(70.6)$ & & \\
\hline $45-54$ & $164(32.9)$ & & $73(82.0)$ & & & $91(59.5)$ & \\
\hline$\geq 55$ & $78(15.6)$ & & $16(18.0)$ & & & $62(40.5)$ & \\
\hline Education (years) & & & & 0.0002 & & & $<0.0001$ \\
\hline$\leq 8$ & $80(16.0)$ & $9(5.8)$ & $21(23.6)$ & & $6(5.9)$ & $44(28.8)$ & \\
\hline $9-15$ & $301(60.3)$ & $91(58.7)$ & $46(51.7)$ & & $72(70.6)$ & $92(60.1)$ & \\
\hline$\geq 16$ & $118(23.7)$ & $55(35.5)$ & $22(24.7)$ & & $24(23.5)$ & $17(11.1)$ & \\
\hline BMI $\left(\mathrm{kg} / \mathrm{m}^{2}\right)$ & & & & 0.0536 & & & 0.1909 \\
\hline Underweight & $12(2.4)$ & $10(6.5)$ & $1(1.1)$ & & 0 & $1(0.7)$ & \\
\hline Normalweight & $328(65.7)$ & $111(71.6)$ & $74(83.2)$ & & $62(60.8)$ & $81(52.9)$ & \\
\hline Overweight & $127(25.5)$ & $25(16.1)$ & $13(14.6)$ & & $35(34.3)$ & $54(35.3)$ & \\
\hline Obesity & $32(6.4)$ & $9(5.8)$ & $1(1.1)$ & & $5(4.9)$ & $17(11.1)$ & \\
\hline Current smoking & & & & 0.5678 & & & 0.003 \\
\hline No & $424(85.0)$ & $128(82.6)$ & $76(85.4)$ & & $80(78.4)$ & $140(91.5)$ & \\
\hline Yes & $75(15.0)$ & $27(17.4)$ & $13(14.6)$ & & $22(21.6)$ & $13(8.5)$ & \\
\hline Alcohol intake & & & & 0.5218 & & & 0.03 \\
\hline No & $120(24.1)$ & $58(37.4)$ & $37(41.6)$ & & $5(4.9)$ & $20(13.1)$ & \\
\hline Yes & $379(76.0)$ & $97(62.6)$ & $52(58.4)$ & & $97(95.1)$ & $133(86.9)$ & \\
\hline Fruits & & & & 0.0709 & & & 0.1615 \\
\hline$<1$ portion/day & $138(27.7)$ & $46(29.7)$ & $16(18.0)$ & & $37(36.3)$ & $39(25.5)$ & \\
\hline $1-2$ portion/day & $278(55.7)$ & $88(56.8)$ & $54(60.7)$ & & $48(47.1)$ & $88(57.5)$ & \\
\hline$>2$ portion/day & $83(16.3)$ & $21(13.6)$ & $19(21.4)$ & & $17(16.7)$ & $26(17.0)$ & \\
\hline Vegetables & & & & 0.0083 & & & 0.7859 \\
\hline$<1$ portion/day & $55(11.0)$ & $15(9.7)$ & $1(1.1)$ & & $15(14.7)$ & $24(15.7)$ & \\
\hline $1-2$ portion/day & $370(74.2)$ & $101(65.2)$ & $72(80.9)$ & & $78(76.5)$ & $119(77.8)$ & \\
\hline$>2$ portion/day & $74(14.8)$ & $39(25.2)$ & $16(18.0)$ & & $9(8.8)$ & $10(6.5)$ & \\
\hline Physical activity & & & & 0.8962 & & & 0.7895 \\
\hline$<2 \mathrm{~h} /$ week & $200(40.1)$ & $68(43.9)$ & $38(42.7)$ & & $40(39.2)$ & $54(35.3)$ & \\
\hline $2-5 \mathrm{~h} /$ week & $197(39.5)$ & $66(42.6)$ & $37(41.6)$ & & $37(36.3)$ & $57(37.3)$ & \\
\hline$>5 \mathrm{~h} /$ week & $102(20.4)$ & $21(13.6)$ & $14(15.7)$ & & $25(24.5)$ & $42(27.5)$ & \\
\hline
\end{tabular}

*P value were obtained by Chi-squared test for the comparison within each gender group, i.e., among females and males, divided by age either $<45$ years or $\geq 45$ years. Underweight and normal weight were considered together

BMI only overweight subjects were related to inadequate concentration of folate.

No significant differences emerged in vitamin B12 for selected characteristics, while female gender and age $\geq 45$ years were associated with inadequate concentration of vitamin B6. Moreover, intake of $\geq 3$ portion/day of fruits and vegetables was associated with adequate concentrations of vitamin B6, while female gender was related to adequate concentration of tHcy (Table 3). No significant differences emerged in $\mathrm{B}$ vitamins for physical activity (Table 3).

\section{One-carbon metabolism-related polymorphisms}

The homozygous mutant allele frequencies were 0.21 for the MTHFR 677TT, 0.11 for the $c S H M T 1420 \mathrm{TT}, 0.18$ for the DHFR $19 \mathrm{bp} \mathrm{del/del} \mathrm{and} 0.20$ for the RFC1 80AA.

Mean plasma folate concentrations were the lowest (13.0, 95\% CIs 11.9-14.2) and tHcy the highest (15.7, 95\% CIs 14.4-17.0) for carriers of the MTHFR 677TT genotype and significantly different for the comparison of the MTHFR $677 T T$ vs. the $677 C C$. The carriers of the DHFR $19 \mathrm{bp} \mathrm{del} /$ del mutant allele showed lower concentrations of vitamin B12 as compared to the DHFR 19 bp ins/ins genotypes. The carriers of the RFC1 80AA and $c S H M T$ 1420TT mutant 


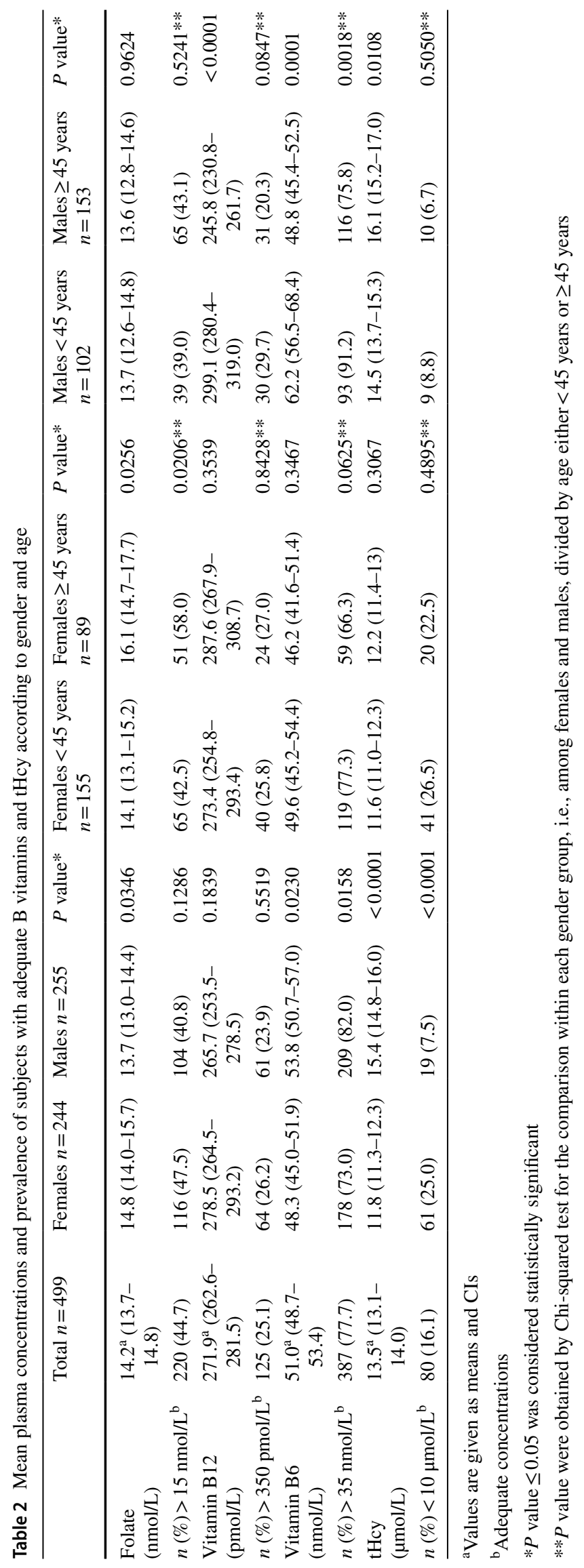


Table 3 Odds ratios for inadequate status of B vitamins and tHcy according to general characteristics and lifestyle factors

\begin{tabular}{|c|c|c|c|c|}
\hline & $\begin{array}{l}\text { Folate } \leq 15 \mathrm{nmol} / \mathrm{L}^{\mathrm{a}} \\
\text { OR }(95 \% \mathrm{CI})^{*}\end{array}$ & $\begin{array}{l}\text { Vitamin } \mathrm{B} 12 \leq 350 \mathrm{pmol} / \mathrm{L}^{\mathrm{a}} \\
\text { OR }(95 \% \mathrm{CI})^{*}\end{array}$ & $\begin{array}{l}\text { Vitamin } \mathrm{B} 6 \leq 35 \mathrm{nmol} / \mathrm{L}^{\mathrm{a}} \\
\text { OR }(95 \% \mathrm{CI})^{*}\end{array}$ & $\begin{array}{l}\mathrm{tHcy} \geq 10 \mu \mathrm{mol} / \mathrm{L}^{\mathrm{a}} \\
\mathrm{OR}(95 \% \mathrm{CI})^{*}\end{array}$ \\
\hline \multicolumn{5}{|l|}{ Gender $^{\mathrm{b}}$} \\
\hline Female & $0.76(0.48-1.18)$ & $0.88(0.53-1.43)$ & $2.54(1.47-4.40)$ & $0.31(0.16-0.58)$ \\
\hline \multicolumn{5}{|l|}{ Age $\left(\right.$ years) ${ }^{b}$} \\
\hline $35-44$ & $0.42(0.22-0.81)$ & $0.90(0.46-1.76)$ & $1.00(0.43-2.40)$ & $0.96(0.94-2.14)$ \\
\hline $45-54$ & $0.59(0.33-1.07)$ & $1.55(0.83-2.90)$ & $2.02(1.00-4.12)$ & $1.12(0.56-2.26)$ \\
\hline$\geq 55$ & $0.44(0.23-0.85)$ & $1.25(0.63-2.47)$ & $2.86(1.31-6.26)$ & $1.45(0.63-3.33)$ \\
\hline \multicolumn{5}{|l|}{ Education $\left(\right.$ years) ${ }^{\mathrm{b}}$} \\
\hline $9-15$ & $0.84(0.47-1.48)$ & $1.16(0.62-2.14)$ & $0.56(0.31-1.00)$ & $1.19(0.54-2.64)$ \\
\hline$\geq 16$ & $0.54(0.28-1.06)$ & $1.15(0.56-2.39)$ & $0.54(0.26-1.14)$ & $1.04(0.43-2.54)$ \\
\hline \multicolumn{5}{|l|}{ BMI $\left(\mathrm{kg} / \mathrm{m}^{2}\right)^{\mathrm{b}}$} \\
\hline Underweight & $1.10(0.30-4.03)$ & $2.05(0.43-9.85)$ & $1.19(0.28-4.99)$ & $1.06(0.26-4.30)$ \\
\hline Overweight & $1.76(1.10-2.83)$ & $1.33(0.79-2.25)$ & $1.39(0.82-2.38)$ & $1.22(0.62-2.38)$ \\
\hline Obesity & $0.69(0.32-1.51)$ & $0.65(0.29-1.43)$ & $1.02(0.40-2.60)$ & $1.11(0.35-3.51)$ \\
\hline \multicolumn{5}{|l|}{ Current smoker ${ }^{\mathrm{b}}$} \\
\hline Yes & $1.30(0.76-2.22)$ & $1.16(0.64-2.10)$ & $1.79(1.00-3.20)$ & $1.35(0.64-2.85)$ \\
\hline \multicolumn{5}{|l|}{ Alcohol drinking ${ }^{\mathrm{b}}$} \\
\hline Yes & $0.96(0.59-1.56)$ & $0.90(0.53-1.51)$ & $0.86(0.51-1.46)$ & $1.19(0.67-2.11)$ \\
\hline \multicolumn{5}{|c|}{ Fruits and vegetables ${ }^{b}$} \\
\hline 2 portion/day & $0.36(0.22-0.57)$ & $0.98(0.60-1.60)$ & $0.65(039-1.08)$ & $0.63(0.32-1.20)$ \\
\hline$\geq 3$ portion/day & $0.27(0.15-0.46)$ & $1.00(0.58-1.89)$ & $0.35(0.18-0.71)$ & $0.49(0.24-1.00)$ \\
\hline \multicolumn{5}{|l|}{ Physical activity ${ }^{\mathrm{b}}$} \\
\hline $2-5 \mathrm{~h} /$ week & $0.80(0.52-1.24)$ & $1.17(0.73-1.89)$ & $0.85(0.52-1.39)$ & $0.95(0.55-1.67)$ \\
\hline$>5 \mathrm{~h} /$ week & $0.67(0.39-1.14)$ & $0.75(0.43-1.30)$ & $0.66(0.34-1.28)$ & $1.06(0.51-2.19)$ \\
\hline
\end{tabular}

OR odds ratio

*Multivariate estimates including in turn term for gender, age, education, BMI, smoking, alcohol drinking, fruits and vegetables intake, physical activity

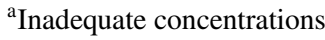

${ }^{b}$ Reference categories: male (gender), $\leq 34$ years (age), $<8$ years (education), normal weight (BMI), no (current smoker), no (alcohol drinking), $<1$ portion/day (fruits and vegetables),$<2 \mathrm{~h} /$ week (physical activity)

genotypes did not show differences as compared to their corresponding wild-type genotypes for any of the B vitamins concentrations. No differences were also observed, in plasma concentrations of vitamin B6, for any of the polymorphisms analysed (data not shown).

As expected, the MTHFR $677 \mathrm{C}>\mathrm{T}$ genotype homozygous mutants (677TT) showed the highest tHcy levels $(18.5 \mu \mathrm{mol} / \mathrm{L})$ with a significant difference between $677 \mathrm{TT}$ group according to plasma concentrations of folate either below or above the median value (18.5 vs. $12.9 \mu \mathrm{mol} / \mathrm{L}$, $P<0.0001$ ) (Table 4).

Comparisons for tHcy according to the RFCl $80 \mathrm{G}>\mathrm{A}$ genotypes showed that those with the lower levels of folate had higher levels of tHcy and there was significant difference within the RFCl 80GG and RFCl 80AA groups according to either low vs. high levels of folate concentrations (Table 5). Similar results were also observed for the $c S H M T 1420 \mathrm{C}>\mathrm{T}$ and the DHFR $19 \mathrm{bp}$ ins/del (Table 5).

\section{Discussion}

This study presents information on blood concentrations of folate, vitamin B12, vitamin B6, tHcy and related polymorphisms frequencies in a sample of healthy, Italian women and men aged 18-65 years, attending a Unit of Transfusion Medicine in Northern Italy.

The sample shows that an adequate concentration of plasma folate and vitamin B12 is reached only in a limited percentage of subjects, and a gene-nutrient interaction is confirmed for folate concentrations according to MTHFR $677 \mathrm{C}>\mathrm{T}$ and DHFR $19 \mathrm{bp} \mathrm{del} / \mathrm{del}$.

A previous study already showed a moderate impairment of B vitamins status in the area of Central-Southern Italy 
Table 4 Mean plasma concentrations of B vitamins and tHcy according to folate status and MTHFR $677 \mathrm{C}>\mathrm{T}$ genotype

\begin{tabular}{|c|c|c|c|c|c|c|}
\hline & \multicolumn{3}{|c|}{ MTHFR $677 \mathrm{CC} n=144$} & \multicolumn{3}{|l|}{ MTHFR $677 \mathrm{TT} n=102$} \\
\hline & Low folate $n=64$ & High folate $n=79$ & $P$ value* & Low folate $n=57$ & High folate $n=42$ & $P$ value* \\
\hline Vitamin $\mathrm{B}_{12}(\mathrm{pmol} / \mathrm{L})$ & $250.0(226.9-275.5)$ & $290.8(270.1-313.1)$ & 0.0131 & $232.9(209.3-259.2)$ & $267.1(235.0-303.5)$ & 0.1012 \\
\hline Vitamin $\mathrm{B}_{6}(\mathrm{nmol} / \mathrm{L})$ & $41.5(36.8-46.7)$ & $54.8(49.8-60.2)$ & 0.0003 & $41.8(37.5-46.7)$ & $53.9(45.2-64.2)$ & 0.0117 \\
\hline tHcy $(\mu \mathrm{mol} / \mathrm{L})$ & $13.4(12.5-14.5)$ & $11.7(11.1-12.4)$ & 0.0034 & $18.5(16.7-20.6)$ & $12.9(11.5-14.4)$ & 0.0001 \\
\hline
\end{tabular}

In some cases, the sum does not add up to the total because of missing value

Values are given as means and CIs

${ }^{*} P$ value $\leq 0.05$ was considered statistically significant; $P$ value was calculated for the comparison of the groups at low vs high plasma folate concentrations defined according to the median value levels $(14.2 \mathrm{nmol} / \mathrm{L})$

Table 5 Mean plasma concentrations of B vitamins and tHcy according to folate status and $c S H M T 1420 \mathrm{C}>\mathrm{T}, \mathrm{DHFR} 19 \mathrm{bp}$ ins/del and RFCl $80 \mathrm{G}>$ A genotypes

\begin{tabular}{|c|c|c|c|c|c|c|}
\hline & \multicolumn{3}{|l|}{$c S H M T 1420 C C n=250$} & \multicolumn{3}{|l|}{$c S H M T 1420 T T n=51$} \\
\hline & $\begin{array}{l}\text { Low folate } \\
(<\text { median value }) \\
n=130\end{array}$ & $\begin{array}{l}\text { High folate } \\
(>\text { median value) } \\
n=118\end{array}$ & $P$ value* & $\begin{array}{l}\text { Low folate } \\
(<\text { median value }) \\
n=30\end{array}$ & $\begin{array}{l}\text { High folate } \\
(>\text { median value) } \\
n=21\end{array}$ & $P$ value* \\
\hline Vitamin $\mathrm{B}_{12}(\mathrm{pmol} / \mathrm{L})$ & $252.7(236.5-269.9)$ & $296.2(275.7-318.2)$ & 0.0014 & $236.9(203.8-275.4)$ & $314.1(276.2-357.1)$ & 0.0080 \\
\hline Vitamin $\mathrm{B}_{6}(\mathrm{nmol} / / \mathrm{L})$ & $44.0(40.4-48.0)$ & $57.7(52.5-63.5)$ & $<0.0001$ & $40.5(34.5-47.6)$ & $52.5(42.1-65.5)$ & 0.0502 \\
\hline \multirow[t]{3}{*}{ tHcy $(\mu \mathrm{mol} / \mathrm{L})$} & $15.2(14.2-16.1)$ & $11.7(11.1-12.4)$ & $<0.0001$ & $15.5(13.6-17.5)$ & $12.3(11.0-13.7)$ & 0.0105 \\
\hline & \multicolumn{3}{|c|}{ DHFR 19 bp ins/ins $n=178$} & \multicolumn{3}{|c|}{$D H F R 19$ bp del $/$ del $n=83$} \\
\hline & $\begin{array}{l}\text { Low folate } \\
(<\text { median value }) \\
n=83\end{array}$ & $\begin{array}{l}\text { High folate } \\
(>\text { median value) } \\
n=95\end{array}$ & $P$ value* & $\begin{array}{l}\text { Low folate } \\
(<\text { median value }) \\
n=40\end{array}$ & $\begin{array}{l}\text { High folate } \\
(>\text { median value) } \\
n=41\end{array}$ & $P$ value* \\
\hline Vitamin $\mathrm{B}_{12}(\mathrm{pmol} / \mathrm{L})$ & $259.7(238.6-282.8)$ & $308.9(287.0-332.4)$ & 0.0024 & $252.1(225.9-281.5)$ & $264.7(229.7-303.9)$ & 0.5977 \\
\hline Vitamin $\mathrm{B}_{6}(\mathrm{nmol} / / \mathrm{L})$ & $45.3(40.9-50.1)$ & $52.4(47.9-57.3)$ & 0.0332 & $45.7(38.8-53.8)$ & $65.5(53.9-79.5)$ & 0.0056 \\
\hline \multirow[t]{3}{*}{ tHcy $(\mu \mathrm{mol} / \mathrm{L})$} & $15.5(14.4-16.7)$ & $11.7(11.1-12.3)$ & $<0.0001$ & $15.1(13.7-16.7)$ & $12.8(11.7-13.9)$ & 0.0123 \\
\hline & \multicolumn{3}{|l|}{ RFC1 80 GG $n=143$} & \multicolumn{3}{|l|}{$R F C 1$ 80AA $n=96$} \\
\hline & $\begin{array}{l}\text { Low folate } \\
(<\text { median value }) \\
n=72\end{array}$ & $\begin{array}{l}\text { High folate } \\
(>\text { median value }) \\
n=69\end{array}$ & $P$ value* & $\begin{array}{l}\text { Low folate } \\
(<\text { median value }) \\
n=55\end{array}$ & $\begin{array}{l}\text { High folate } \\
(>\text { median value) } \\
n=40\end{array}$ & $P$ value* \\
\hline Vitamin $\mathrm{B}_{12}(\mathrm{pmol} / \mathrm{L})$ & $251.7(231.0-274.3)$ & $296.2(270.7-324.1)$ & 0.0100 & $262.8(237.4-290.8)$ & $291.8(256.7-331.6)$ & 0.1950 \\
\hline Vitamin $\mathrm{B}_{6}(\mathrm{nmol} / / \mathrm{L})$ & $42.1(38.0-46.7)$ & $58.1(51.8-65.3)$ & $<0.0001$ & $47.3(41.4-54.1)$ & $64.4(55.1-75.3)$ & 0.0034 \\
\hline tHcy $(\mu \mathrm{mol} / \mathrm{L})$ & $16.2(14.9-17.5)$ & $11.8(10.9-12.7)$ & $<0.0001$ & $15.5(14.1-17.1)$ & $11.6(10.7-12.7)$ & $<0.0001$ \\
\hline
\end{tabular}

Values are given as means and CIs

${ }^{*} P$ value $\leq 0.05$ was considered statistically significant; $P$ value was calculated for the comparison of the groups at low vs. high plasma folate concentrations defined according to the median value levels $(14.2 \mathrm{nmol} / \mathrm{L})$

[7]. The results of our study also show no substantial differences for the percentage of subjects with adequate folate status among males and females. Interestingly, this study highlights that a large portion of healthy blood donors has an impaired vitamin B12 status and an inadequate status of tHcy especially in males, confirming previous studies [7, 21]. Results from this study, furthermore, confirm the higher plasma concentrations of folate among subjects with greater consumption of fruits and vegetables [7, 22].

Several studies evaluated folate, vitamin B12 and B6 status, and tHcy concentrations, in research with a rather diversified study design, where the cut-off used, the presence of food fortification, the lifestyle and dietary habits of population make the comparison among studies difficult. We referred to the cut-off values according to Dhonukshe-Rutten et al. [2] and Daly et al. [19] for the prevention of cardiovascular diseases and NTDs, with the knowledge that such values do not necessarily reflect a nutritional deficiency but rather a cut-off value associated to the prevention of these events $[2-5,8,19]$.

A systematic review evaluating more than sixty studies, showed the B vitamin status was inadequate in several 
European countries [2]. In the IMMIDIET Project [23], among Italian and British women of childbearing age, the $66.7 \%$ and $22.1 \%$ of, respectively, showed folate serum concentrations $<15 \mathrm{nmol} / \mathrm{L}$, similarly to the results of the present study.

In our study there was no association of folate status with either smoking and alcohol intake. Regarding smoking habit, a previous research in Italian blood donors showed no association when analyzed folate concentrations in blood [24], but low serum folate was related with smoking in others [23, 25]. Moreover, studies that evaluated the effects of alcohol consumption on serum folate indicated that the relationship could depend on the type of alcoholic beverage consumed [26].

An association was observed between plasma folate and BMI that was statistically significant only in overweight persons. As for folate status in obese women of childbearing age [27] and the impact of BMI on plasma folate in adults [28] there are few and conflicting results.

In the United States, age and dietary supplements had the greatest effects on prevalence estimates of low folate concentrations during the pre-fortification period [29, 30].

As for women in childbearing age, the present study shows adequate levels of plasma folate in $39.9 \%$ of women (cut-off $\geq 15.9 \mathrm{nmol} / \mathrm{L}$ [19]). In a previous study by Zappacosta et al. [7], when the cut-off of RBCs folate used was $\geq 906 \mathrm{nmol} / \mathrm{L}-1$ [19], no women of childbearing age had adequate levels (7). These results were confirmed in a Swedish population [31].

Fayyaz et al. [32] described folate, vitamin B12 and B6 status in the Alberta Pregnancy Outcomes and Nutrition cohort. Folate deficiency was rare (3\%), as well as vitamin B12 and B6 $(<1 \%)$, but $24 \%$ of women in their first trimester of pregnancy had suboptimal RCFs concentrations if considered for values $<906 \mathrm{nmol} / \mathrm{L}$ [32].

Our results indicate inadequate concentrations of vitamin B12 in most blood donors, especially in men $\geq 45$ years and are similar to those by Sofi et al. [21], but not others [25, 33-35].

Regarding vitamin B6, adequate concentrations were observed in $77.7 \%$ of total blood donors in the present study, with significant differences for gender and age. Studies that evaluated the status of vitamin B6 were conducted mainly in the elderly population [36] and in relationship to cognitive functions [37, 38]. Determinants of PLP concentrations were also investigated [39-41].

A moderate reduction of PLP $(36.3 \mathrm{nmol} / \mathrm{L})$ was found to be inversely related to major markers of inflammation and independently associated with increased coronary artery disease risk in an Italian cohort and in the US participants from the population-based Framingham Heart Study cohort [42], showing that a mild vitamin B6 impairment is associated to major disease risk.
B vitamins have been mostly related to the risk of major chronic diseases in relationship to their role as determinants of tHcy [3,4]. As consistently reported in most of the studies $[2,43]$, tHcy levels were inversely correlated with folate and serum vitamin B12 concentrations. As for the plasma concentrations of tHcy in the present study we observed higher levels of tHcy in men than in women, according to previous reports [2], where the authors observed that tHcy levels differed to a great extent between countries: from 7.1 to $14.8 \mu \mathrm{mol} / \mathrm{L}$. Also in Italy the concentrations varied greatly $[8,21]$. In our study, unlike others $[44,45]$, no significant differences emerged in tHcy for lifestyle factors.

As for the one-carbon metabolism-related genotypes, as expected the frequencies observed in the present study were similar to those reported in other European populations [3, 11-13, 16, 17]. The MTHFR $677 \mathrm{C}>\mathrm{T}$ genotype was related to higher concentrations of tHcy according to folate status as previously reported [3], but also by other genotypes such as the $c S H M T 1420 \mathrm{C}>\mathrm{T}$, the DHFR $19 \mathrm{bp}$ ins/del and the $R F C 180 \mathrm{G}>\mathrm{A}$ when data were analysed according to the median folate status. This finding is important to highlight the role of a gene-nutrient interaction with B vitamins for those common polymorphisms.

The study has some weaknesses and strengths. This crosssectional study is based on a small and possibly specific population, perhaps not representative of the Italian healthy adult population. We evaluated blood donors, considered a healthier group than the majority of people and results expected in the general population could be different. Nevertheless, we approached this potential bias by balancing the age and sex groups.

Moreover, elderly people are not eligible for blood donation and, therefore, excluded.

In our study we assessed the folate status of subjects by measuring serum folate concentrations. The World Health Organization released guidelines that recommend RBCs folate concentrations above $906 \mathrm{nmol} / \mathrm{L}$, using the microbiologic assay, for optimal protection from NTD-affected pregnancy [46]. The RBCs folate concentration should be used to evaluate such risk among different populations of childbearing age women. However, many population-based surveys do not measure RBCs folate concentrations and this methodology is not widely available in all countries, including Italy. Furthermore, some authors consider the serum assay, when available, an efficient marker to define folate status [47-49].

Finally, the cut-off used, the presence of mandatory food fortification, lifestyle and dietary habits of population investigated in different contexts and subgroups, make the comparison difficult.

Among the strengths of this study design, there is the fact of having evaluated people living in a European country without mandatory fortification, having also analysed 
the allele frequency of common genetic variants related to B-vitamins metabolism and, therefore, highlighting gene-nutrient interaction relationships with possible implication for nutritional policies in our population.

Considering the role of folate status in the prevention of birth defects and major chronic diseases, diversified intervention strategies should be implemented. Specifically, for women of childbearing age, although the prevalence of preconception folic acid supplementation in Europe has increased after many years of delivered recommendations, a large number of women still do not follow the recommendations and a lot of them start the supplementation too late [50].

Regarding vitamin B12, no associations were found between serum levels of vitamin B12 and selected characteristics considered. This makes the reasons of the inadequate B12 status in blood donors difficult to understand, but an important priority to be explored.

The results of the present cross-sectional study confirm inadequate concentrations of serum folate, vitamin B12 and tHcy in Italian women and men between 18 and 65 years. Public health strategies and integrated intervention programs should be undertaken and implemented, especially in subgroups of population with special needs, such as women of childbearing age.

Acknowledgements The work was performed in part in the LURM Research Centre, University of Verona (Italy).

Author contribution The authors' responsibilities were as follows$\mathrm{RB}, \mathrm{FP}$, and SF developed the study concept and designed the research; FF, MR, GDG, and OO conducted the research and collected the data; $\mathrm{MM}, \mathrm{GL}, \mathrm{SU}$, and PP were responsible for the biochemical and genetic analysis; FC and FP performed the statistical data analysis; RB and SF wrote the manuscript; and all authors were responsible for critical revision of the manuscript and read and approved the final manuscript.

Funding Open access funding provided by Università degli Studi di Verona within the CRUI-CARE Agreement.. This work was supported by unconditional grant from Bayer S.p.A. The funder had no role in study design, data collection, analysis or interpretation; or writing manuscript.

\section{Compliance with ethical standards}

Conflict of interest FP was involved in Bayer Italy and Sanofi Italy Board. The other authors report no conflicts of interest.

Ethical approval The study was approved by the Ethical Committee of the Verona University Hospital. Eligible subjects were informed about the objectives and procedures of the study. All participants provided written informed consent before enrolment. The procedures used were in accordance with the ethical standards of the responsible institutional or regional committee on human experimentation or in accordance with the Helsinki Declaration of 1975 as revised in 1983.
Open Access This article is licensed under a Creative Commons Attribution 4.0 International License, which permits use, sharing, adaptation, distribution and reproduction in any medium or format, as long as you give appropriate credit to the original author(s) and the source, provide a link to the Creative Commons licence, and indicate if changes were made. The images or other third party material in this article are included in the article's Creative Commons licence, unless indicated otherwise in a credit line to the material. If material is not included in the article's Creative Commons licence and your intended use is not permitted by statutory regulation or exceeds the permitted use, you will need to obtain permission directly from the copyright holder. To view a copy of this licence, visit http://creativecommons.org/licenses/by/4.0/.

\section{References}

1. De-Regil LM, Peña-Rosas JP, Fernández-Gaxiola AC, RaycoSolon P (2015) Effects and safety of periconceptional oral folate supplementation for preventing birth defects. Cochrane Database Syst Rev. https://doi.org/10.1002/14651858.CD007950.pub3

2. Dhonukshe-Rutten RAM, de Vries JHM, de Bree A, van der Put N, van Staveren WA, de Groot LCPGM (2009) Dietary intake and status of folate and vitamin B12 and their association with homocysteine and cardiovascular disease in European populations. Eur J Clin Nutr 63:18-30

3. Girelli D, Friso S, Trabetti E, Olivieri O, Russo C, Pessotto R, Faccini G, Pignatti PF, Mazzucco A, Corrocher R (1998) Methylenetetrahydrofolate reductase C677T mutation, plasma homocysteine, and folate in subjects from northern Italy with or without angiographically documented severe coronary atherosclerotic disease: evidence for an important genetic-environmental interaction. Blood 91:4158-4163

4. Friso S, Girelli D, Martinelli N, Olivieri O, Lotto V, Bozzini C, Pizzolo F, Faccini G, Beltrame F, Corrocher R (2004) Low plasma vitamin B-6 concentrations and modulation of coronary artery disease risk. Am J Clin Nutr 79:992-998

5. Pfeiffer CM, Caudill SP, Gunter EW, Osterloh J, Sampson EJ (2005) Biochemical indicators of B vitamin status in the US population after folic acid fortification: results from the National Health and Nutrition Examination Survey 1999-2000. Am J Clin Nutr 82:442-450

6. Parazzini F, Chiaffarino F, Ricci E, Improta L, Monni G (2011) Homocysteine in Pregnancy Study Group. Homocysteine, red cell, and plasma folate concentrations and birth weight in Italian women: results from a prospective study. J Matern Fetal Neonatal Med 24(3):427-431

7. Zappacosta B, Persichilli S, Iacoviello L, Di Castelnuovo A, Graziano M, Gervasoni J, Leoncini E, Cimino G, Mastroiacovo P (2013) Folate, vitamin B12 and homocysteine status in an Italian blood donor population. Nutr Metab Cardiovasc Dis 23:473-480

8. Girelli D, Martinelli N, Pizzolo F, Friso S, Olivieri O, Stranieri C, Trabetti E, Faccini G, Tinazzi E, Pignatti PF, Corrocher R (2003) The interaction between MTHFR $677 \mathrm{C}->$ T genotype and folate status is a determinant of coronary atherosclerosis risk. J Nutr 133(5):1281-1285

9. Bonaccio M, Di Castelnuovo A, Bonanni A, Costanzo S, De Lucia F, Persichillo M, Zito F, Donati MB, de Gaetano G, Iacoviello L (2014) Decline of the Mediterranean diet at a time of economic crisis. Results from the Moli-sani study. Nutr Metab Cardiovasc Dis 24(8):853-860

10. Liew SC, Gupta ED (2015) Methylenetetrahydrofolate reductase (MTHFR) C677T polymorphism: epidemiology, metabolism and the associated diseases. Eur J Med Genet 58(1):1-10 
11. Stanisławska-Sachadyn A, Brown KS, Mitchell LE, Woodside JV, Young IS, Scott JM, Murray L, Boreham CA, McNulty H, Strain JJ, Whitehead AS (2008) An insertion/deletion polymorphism of the dihydrofolate reductase (DHFR) gene is associated with serum and red blood cell folate concentrations in women. Hum Genet 123(3):289-295

12. Gellekink H, Blom HJ, van der Linden IJ, den Heijer M (2007) Molecular genetic analysis of the human dihydrofolate reductase gene: relation with plasma total homocysteine, serum and red blood cell folate levels. Eur J Hum Genet 15(1):103-109

13. Chango A, Emery-Fillon N, de Courcy GP, Lambert D, Pfister M, Rosenblatt DS, Nicolas JP (2000) A polymorphism (80G->A) in the reduced folate carrier gene and its associations with folate status and homocysteinemia. Mol Genet Metab 70(4):310-315

14. Stover PJ, Chen LH, Suh JR, Stover DM, Keyomarsi K, Shane B (1997) Molecular cloning, characterization, and regulation of the human mitochondrial serine hydroxymethyltransferase gene. J Biol Chem 272(3):1842-1848

15. Frosst P, Blom HJ, Milos R, Goyette P, Sheppard CA, Matthews RG, Boers GJ, den Heijer M, Kluijtmans LA, van den Heuvel LP et al (1995) A candidate genetic risk factor for vascular disease: a common mutation in methylenetetrahydrofolate reductase. Nat Genet 10(1):111-113

16. Heil SG, Van der Put NM, Waas ET, den Heijer M, Trijbels FJ, Blom HJ (2001) Is mutated serine hydroxymethyltransferase (SHMT) involved in the etiology of neural tube defects? Mol Genet Metab 73(2):164-172

17. Johnson WG, Stenroos ES, Spychala JR, Chatkupt S, Ming SX, Buyske S (2004) New 19 bp deletion polymorphism in intron-1 of dihydrofolate reductase $(D H F R)$ : a risk factor for spina bifida acting in mothers during pregnancy? Am J Med Genet A 124A(4):339-345

18. Cook JD, Skikne BS (1989) Iron deficiency: definition and diagnosis. J Intern Med 226:349-355

19. Daly LE, Kirke PN, Molloy A, Weir DG, Scott JM (1995) Folate levels and neural tube defects. JAMA 274(21):1698-1702

20. Chen MY, Rose CE, Qi YP, Williams JL, Yeung LF, Berry RJ, Hao L, Cannon MJ, Crider KS (2019) Defining the plasma folate concentration associated with the red blood cell folate concentration threshold for optimal neural tube defects prevention: a population-based, randomized trial of folic acid supplementation. Am J Clin Nutr 109:1452-1461

21. Sofi F, Vecchio S, Giuliani G, Martinelli F, Marcucci R, Gori AM, Fedi S, Casini A, Surrenti C, Abbate R, Gensini GF (2005) Dietary habits, lifestyle and cardiovascular risk factors in a clinically healthy Italian population: the 'Florence' diet is not Mediterranean. Eur J Clin Nutr 59:584-591

22. Marchetta CM, Devine OJ, Crider KS, Tsang BL, Cordero AM, Qi YP, Guo J, Berry RJ, Rosenthal J, Mulinare J, Mersereau P, Hamner HC (2015) Assessing the association between natural food folate intake and blood folate concentrations: a systematic review and Bayesian meta-analysis of trials and observational studies. Nutrients 7:2663-2686

23. Pounis G, Di Castelnuovo AF, de Lorgeril M, Krogh V, Siani A, Arnout J, Cappuccio FP et al (2014) Folate intake and folate serum levels in men and women from two European populations: The IMMIDIET project. Nutrition 30:822-830

24. Cafolla A, Dragoni F, Girelli G, Tosti ME, Costante A, Pastorelli D, Bedogni G, Scott S (2000) Folate status in Italian blood donors: relation to gender and smoking. Haematologica 85:694-698

25. Thuesen BH, Husemoen LL, Ovesen L, Jorgensen T, Fenger M, Linneberg A (2010) Lifestyle and genetic determinants of folate and vitamin B12 levels in a general adult population. Br J Nutr 103:1195-1204

26. van der Gaag MS, Ubbink JB, Sillanaukee P et al (2000) Effect of consumption of red wine, spirits, and beer on serum homocysteine. Lancet 355:1522

27. Maffoni S, De Giuseppe R, Stanford FC, Cena H (2017) Folate status in women of childbearing age with obesity: a review. Nutr Res Rev 30:265-271

28. Nakazato M, Maeda T, Takamura N, Wada M, Yamasaki H, Johnston KE, Tamura T (2011) Relation of body mass index to blood folate and total homocysteine concentrations in Japanese adults. Eur J Nutr 50:581-585

29. Pfeiffer CM, Hughes JP, Lacher DA, Bailey RL, Berry RJ, Zhang M, Yetley EA, Rader JI, Sempos CT, Johnson CL (2012) Estimation of trends in serum and RBC folate in the U.S. population from pre- to postfortification using assay-adjusted data from the NHANES 1988-2010. J Nutr 142:886-893

30. Pfeiffer CM, Sternberg MR, Zhang M, Fazili Z, Storandt RJ, Crider KS, Yamini S, Gahche JJ, Juan WY, Wang CY, Potischman N, Williams J, LaVoie DJ (2019) Folate status in the US population 20 years after the introduction of folic acid fortification. Am J Clin Nutr 110:1088-1097

31. Ohrvik V, Lemming EW, Nalsen C, Becker W, Ridefelt P, Lindroos AK (2018) Dietary intake and biomarker status of folate in Swedish adults. Eur J Nutr 57:451-462

32. Fayyaz F, Wang F, Jacobs RL, O'Connor DL, Bell RC, Field CJ, APrON Study Team (2014) Folate, vitamin B12, and vitamin B6 status of a group of high socioeconomic status women in the Alberta Pregnancy Outcomes and Nutrition (APrON) cohort. Appl Physiol Nutr Metab 39(12):1402-1408

33. Schwettmann L, Berbu S (2015) Reference interval and status for serum folate and serum vitamin B12 in a Norwegian population. Clin Lab 61(8):1095-1100

34. MacFarlane AJ, Shi Y, Greene-Finestone LS (2014) High-dose compared with low-dose vitamin B-12 supplement use is not associated with higher vitamin B-12 status in children, adolescents, and older adults. J Nutr 144:915-920

35. Qi YP, Do AN, Hamner HC, Pfeiffer CM, Berry RJ (2014) The prevalence of low serum vitamin B12 status in the absence of anemia or macrocytosis did not increase among older U.S. adults after mandatory folic acid fortification. J Nutr 144:170-176

36. Laird E, Casey MC, Ward M, Hoey L, Hughes CF, McCarroll K, Cunningham C, Strain JJ, McNulty H, Molloy AM (2017) Dairy intakes in older Irish adults and effects on vitamin micronutrient status: data from the TUDA study. J Nutr Health Aging 21:954-961

37. Rutjes AW, Denton DA, Di Nisio M, Chong LY, Abraham RP, Al-Assaf AS, Anderson JL, Malik MA, Vernooij RW, Martinez G, Tabet N, McCleery J (2018) Vitamin and mineral supplementation for maintaining cognitive function in cognitively healthy people in mid and late life. Cochrane Database Syst Rev 12:CD011906. https://doi.org/10.1002/14651858.CD011 906.pub2

38. Palacios N, Scott T, Sahasrabudhe N, Gao X, Tucker KL (2019) Lower plasma vitamin B-6 is associated with 2-year cognitive decline in the Boston Puerto Rican health study. J Nutr 149:635-641

39. Jungert A, Neuhauser-Berthold M (2019) Longitudinal analysis on determinants of vitamin B6 status in community-dwelling older adults over a period of 18 years. J Gerontol A Biol Sci Med Sci. https://doi.org/10.1093/gerona/glz010 
40. Ho C, Quay TA, Devlin AM, Lamers Y (2016) Prevalence and predictors of low vitamin B6 status in healthy young adult women in metro Vancouver. Nutrients 8:538

41. Page JH, Ma J, Chiuve SE, Stampfer MJ, Selhub J, Manson JE, Rimm EB (2009) Plasma vitamin B6 and risk of myocardial infarction in women. Circulation 120:649-655

42. Friso S, Jacques PF, Wilson PW, Rosenberg IH, Selhub J (2001) Low circulating vitamin B (6) is associated with elevation of the inflammation marker C-reactive protein independently of plasma homocysteine levels. Circulation 103:2788-2791

43. Homocysteine Lowering Trialists' Collaboration (2005) Dosedependent effects of folic acid on blood concentrations of homocysteine: a meta-analysis of the randomized trials. Am J Clin Nutr 82:806-812

44. Mennen LI, de Courcy GP, Guilland JC, Ducros V, Bertrais S, Nicolas JP, Maurel M, Zarebska M, Favier A, Franchisseur C, Hercberg S, Galan P (2002) Homocysteine, cardiovascular disease risk factors, and habitual diet in the French
Supplementation with Antioxidant Vitamins and Minerals Study. Am J Clin Nutr 76:1279-1289

45. de Bree A, Verschuren WM, Blom HJ, Kromhout D (2001) Lifestyle factors and plasma homocysteine concentrations in a general population sample. Am J Epidemiol 154:150-154

46. WHO (2015) Guideline: Optimal serum and red blood cell folate concentrations in women of reproductive age for prevention of neural tube defects. World Health Organization, Geneva

47. Jaffe JP, Schilling RF (1991) Erythrocyte folate levels: a clinical study. Am J Hematol 36:116-121

48. Phekoo K, Williams Y, Schey SA, Andrews VE, Dudley JM, Hoffbrand AV (1997) Folate assays: serum or red cell? JR Coll Physicians Lond 31:291-295

49. Farrell CJ, Kirsch SH, Herrmann M (2013) Red cell or serum folate: what to do in clinical practice? Clin Chem Lab Med 51:555-569

50. Bortolus R, Parazzini F, Addis A (2017) Folic acid for the prevention of neural tube defects. JAMA Pediatr 171:709-710 